\title{
The Effect of Application Guessing Game Pic-Pow Strategy Towards Students' Speaking Mastery at the First Class of SMA Mathla'ul Anwar Menes
}

\author{
Karlina $^{1}$, Ade Sudirman ${ }^{2}$ \\ ${ }^{1}$ English Education Study Program of Teacher Training and Education Faculty, Universitas Mathla'ul Anwar Banten \\ ${ }^{2}$ English Education Study Program of Teacher Training and Education Faculty, Universitas Mathla'ul Anwar Banten
}

ARTICLE INFO

Keywords:

Speaking Mastery

Application Guessing

Game Pic-Pow Strategy

\begin{abstract}
This research aims to investigate the effect of application guessing game pic-pow strategy towards students' speaking mastery at the first class of SMA Mathla'ul Anwar Menes. It employs the quantitative research with the characteristics of the true experimental design. It uses achievement test in collecting data involving orally pre and post tests. The findings reveal that application guessing game pic-pow strategy is able to help students to improve their speaking skill mastery. In the pre-test, the mean of experimental class is 38 and the mean of control class is 39,13 while in the post-test the mean of experimental class is 92,75 and mean of control class is 79,29 . In the post test of t-test, the researcher can conclude that tcount $\geq$ ttable or 3, $0858 \geq 1,672$ therefore Ha is accepted and there is a significant effect of application guessing game pic-pow strategy towards students' speaking mastery.
\end{abstract}

This is an open access article distributed under the terms of the Creative Commons Attribution 4.0 International License, which permits unrestricted use, distribution, and reproduction in any medium, provided the original work is properly cited. @ 2019 Karlina, Ade Sudirman

\section{INTRODUCTION}

Look at the sequence and technology, language has an important rule for human life, by using language people well express their ideas, emotion, and desires, and it is used to interact with one another. English the most important language in international communication, the people all over the work speak the language when they meet one another in every international meeting, workshop or conference. English has been considered as an international language. Almost all the people from many different countries around the world use it to communicate, it's because of the importance of English in any scope of our lives. English has many functions, one of them as started in the 2004 curriculum that English is means for the students to develop science,

\footnotetext{
${ }^{1}$ Corresponding author's address: English Education Study Program of Teacher Training and Education Faculty, Universitas Mathla'ul Anwar, Banten, Indonesia e-mail: lkarlina055@gmail.com

2 Corresponding author's address: English Education Study Program of Teacher Training and Education Faculty, Universitas Mathla' ul Anwar, Banten, Indonesia e-mail: adesudirman03@gmail.com
} 
technology, culture and art, and the final objective of teaching and learning process is the students are expected to master the four skill of language: listening, speaking, reading and writing.

Language is a tool that humans to communication with one another and build complex societies. One of the ways in communication is through speaking. Speaking is a sort of productive skill which is used in oral model. It means that through speaking people produce words, expressions, or utterance to express our ideas, feelings as well as to respond towards particular situations. Speaking is a process deliver message who expression thought sound. Better if that message without problem, so listener feel comfortable when communication. But in the fact, there are several problems of the speaking still happen, like as many people often silent and thinking material to discussion and make some certain sounds (hmmm, emmm, etc.) or it called filler, and the speaker's confident is still low for speaking English and sometimes although have many material to speak but, suddenly it can lose, and slender of the problem speaking is less of vocabulary.

Those problems were also found in Mathla'ul Anwar Senior High School Menes based on the interview from one of the English teacher there. Most of the students still feel reluctant to speak, they feel anxiety and difficult to express their ideas in a conversation. They thought about the pronunciation, feel doubt and afraid of making mistakes. Therefore, it reminds the researcher about our responsibility to be a good facilitator to help the students to solve their problem. Those problems are that: 1 ) the students have low speaking mastery; 2) the students have low motivation in learning English; and 3) the teacher still uses monotonous and inappropriate teaching strategies.

Because the problem in English teaching and learning are very variety, so the teacher are obligated to choose the suitable strategy to achieve the teaching purposes easily, and the media will make the students to be more motivated to study. The teacher who is able to present the material easily will be students' idol. The teacher can use some strategy in teaching learning process to help the students understanding about the material that was explained.

There are many ways to improve speaking children in speaking English, one of the best simple ways is through game. In this opportunity the researchers focused on the application of guessing game pic-pow to improve speaking in English. It is a game where the player must answer by guessing the image that is inserted in the power point correctly. Guessing game pic-pow can be an alternative to learning English that is fun, especially when students are getting bored in conventional ways which may be applied at each meeting by the teacher. If a teacher cannot control and or change the boredom, then surely the students are more dizzy and lazy to learn English.

Based on the things mentioned above, the researcher tried to make speaking activities more effective for students in learning English by determining the strategy which are appropriate and effective to teach speaking. The researcher tried to use application guessing game pic-pow in order to increase the students speaking mastery, as an effort to make the students able to use English communicate.

\section{Speaking}

Speaking is the main means to foster mutual understanding, reciprocal communication by using language as a medium. Because by talking we can find out who is taking and what information will be conveyed besides, speaking is also very important in maintaining friendship between family, friends and people who are just known. According to Zaher (2006:14), "Speaking is closely related to listening as two interrelated ways of accomplishing communication". Student will better understand the lesson if there is a greeting from a teacher to review the lessons that students read before, because who read in the class have not understood the contents of the reading they read even though they have repeated several times. Hence from that speaking is much needed in the teaching learning process. Zulaikho et al (2018:105) also said that Speaking is the process of communication or interaction with other people in order to communicate each other. Every 
human cannot live alone they need other people to talk too, help each other in a problem and communicate to solve the problem.

From those statements, could be synthesized that speaking is one of the most important role in people's communicating life among one and another. By communicating they are able to create relationship, inform, share and find information. In this case, speaking is the most important part in expressing the students' ideas, opinion, though or feelings and they are able to communicative with others by doing some activities in classroom.

\section{Types of Classroom Speaking Performance}

Classroom Speaking Performance is a speaking appearance performed by students to convey intentions, ideas, information, etc.

Brown (2001: 271-274) suggest some types of classroom speaking performance as follows:

a. Imitative

A very limited portion of classroom speaking time may legitimately be spent generating "human recorder" speech, where, for example, learners practice an intonation contour or try to pinpoint a certain vowel sounds. Imitation of this kind is carried out not for the purpose of meaningful interaction, but for focusing on some particular element of language form.

b. Intensive

Intensive speaking goes one step beyond imitative to include any speaking performance that is designed to practice some phonological or grammatical aspect of language. Intensive speaking can be self-initiated or it can even form part of some pair work activity, where learners are "going over" certain forms of language.

c. Responsive

A good deal of student speech in the classroom is responsive. Short replies to teacher, or student initiated questions or comments. These replies are usually sufficient and do not extend into dialogues.

d. Transactional (dialogues)

Transactional language, carried out for purpose of conveying or exchanging specific information, is an extended form of responsive language.

e. Interpersonal (dialogues)

The other form of conversation was interpersonal dialogue, carried out more for the purpose of maintaining social relationship than for the transmission of facts and information.

f. Extensive (monologues)

Finally, students at intermediate to advance levels are called on to give extended monologues in the form of oral reports, summaries, or perhaps short speeches. Here the register is more formal and deliberative. These monologues can be planned or important.

Based on types of speaking above, the researcher focused her research more requires a short response to information conveyed in front of the class by students and teachers and not to dialogue. This research focused on information, because here students provide information to classmates. In speaking there are also several aspects that support speaking easily understood and approved by people in the world. Aspects in speaking include; grammar, vocabulary, pronunciation, and comprehension.

According to Wahyuni and Yulianti (2017:14) the Aspects of Speaking divided by 3 parts, they are:

1. Accuracy

a. Grammar

Grammar is structure words that is arranged to be sentences to give meaning, it is needed for students to arrange a correct sentence in conversation.

b. Vocabulary

It means vocabulary is one of the speaking components which are very important in mastering English. 


\section{c. Pronunciation}

It deals with the phonological process that refers to the components of a grammar made up of the elements and principles that determine how sounds vary and pattern in a language. There are two features of pronunciation; phonemes and supra segmental features. A speaker who constantly mispronounces a range of phonemes can be extremely difficult for a speaker from another language community to understand.

\section{Fluency}

The main goal of teaching speaking is oral fluency. Fluency mean as the ability to speak fluently and accurately. Fluency in speaking is the aim of many language learners. Symbol of fluency consist of a logically fast speed of speaking and only a small number of pauses and "ums" or "ems". These symbols show that the speaker does not have to spend a lot of time searching for the language items needed to express the message.

\section{Comprehension}

Heroine (2014:7) suggested teachers have to ensure that students are paying attention and understanding the material. It means conducting comprehension checks will highlight what students are struggling with and what needs to be covered more thoroughly before completing additional activities or moving on the next topic. Consequently, the teacher can do the comprehension exercises often determined by the type of activities, and then teacher have decided to include in his lessons. Most of the comprehension checks for speaking exercises will be done during the initial introduction and practice sections of the lesson.

Based on the statement above that aspects of speaking are divided into 3 parts, namely accuracy, fluency and comprehension. In accuracy divided into 3 parts, namely grammar, which server to sort words or sentences so that they have meaning that can be easily understood, the second is a vocabulary that functions to master a language, because that more vocabularies that students have, that more students' knowledge of the language becomes richer, and the third is pronunciation, which serves to help students distinguish how to read letters, words and sentence. Fluency is the fluency of a student in speaking English without pause when speaking, and comprehension of a student's understanding of the teacher when speaking in English or vice versa.

Assessment rubrics are a tool to assess student achievement in understanding the material presented. In general there are two types of rubrics namely holistic and analytical. Holistic rubrics allow scores to make judgments about performance (product processes) as a whole, regardless of parts of the scorers to assess the components of separate components or individual assignments related to the intended performance.

Table 1. Rubric of Speaking

\begin{tabular}{|c|c|c|c|c|c|}
\hline & Grammar & Vocabulary & Comprehension & Fluency & Pronunciation \\
\hline 1 & $\begin{array}{l}\text { Error in grammar } \\
\text { are frequent, but } \\
\text { speaker can be } \\
\text { understood by a } \\
\text { native speaker used } \\
\text { to dealing with } \\
\text { foreigners } \\
\text { attempting to speak } \\
\text { his language. }\end{array}$ & $\begin{array}{l}\text { Speaking vocabulary } \\
\text { inadequate to express } \\
\text { anything but the most } \\
\text { elementary needs. }\end{array}$ & $\begin{array}{l}\text { Within the scope of his } \\
\text { very limited language } \\
\text { experience, can } \\
\text { understand simple } \\
\text { questions and } \\
\text { statements if delivered } \\
\text { with slowed speech, } \\
\text { repetition, } \\
\text { paraphrase. }\end{array}$ & $\begin{array}{l}\text { (No specific fluency } \\
\text { description. Refer to } \\
\text { other four language } \\
\text { areas for implied level } \\
\text { of fluency). }\end{array}$ & $\begin{array}{l}\text { Error in pronunciation are } \\
\text { frequent but can be } \\
\text { understood by a native } \\
\text { speaker used to dealing } \\
\text { with foreigners } \\
\text { attempting to speak his } \\
\text { language. }\end{array}$ \\
\hline 2 & $\begin{array}{l}\text { Can usually handle } \\
\text { elementary } \\
\text { constructions quite } \\
\text { accurately but does } \\
\text { not have thorough } \\
\text { or confident control } \\
\text { of the grammar. }\end{array}$ & $\begin{array}{l}\text { Has speaking vocabulary } \\
\text { sufficient to express } \\
\text { himself simply with some } \\
\text { circumlocutions. }\end{array}$ & $\begin{array}{l}\text { Can get the gist of } \\
\text { most conversations of } \\
\text { non-technical subject } \\
\text { (i.e., topics that } \\
\text { require not specialized } \\
\text { knowledge). }\end{array}$ & $\begin{array}{lr}\text { Can handle with } \\
\text { confidence but not } \\
\text { with facility most } \\
\text { social situations, } \\
\text { including } \\
\text { introductions and } \\
\begin{array}{l}\text { casual conversations } \\
\text { about current events, }\end{array}\end{array}$ & $\begin{array}{l}\text { Accent is intelligible } \\
\text { though often quite faulty. }\end{array}$ \\
\hline
\end{tabular}




\begin{tabular}{|c|c|c|c|c|c|}
\hline & & & & $\begin{array}{l}\text { as well as work, family, } \\
\text { and autobiographical } \\
\text { information. }\end{array}$ & \\
\hline 3 & $\begin{array}{l}\text { Control of grammar } \\
\text { is good. Able to } \\
\text { speak the language } \\
\text { with sufficient } \\
\text { structural accuracy } \\
\text { to participate } \\
\text { effectively in most } \\
\text { formal and informal } \\
\text { conversations on } \\
\text { practical, social, and } \\
\text { professional topics. }\end{array}$ & $\begin{array}{l}\text { Able to speak the } \\
\text { language with sufficient } \\
\text { vocabulary to participate } \\
\text { effectively in most formal } \\
\text { and informal } \\
\text { conversations on practical, } \\
\text { social, and professional } \\
\text { topics. Vocabulary is } \\
\text { broad enough that he } \\
\text { rarely has to grope for a } \\
\text { word. }\end{array}$ & $\begin{array}{l}\text { Comprehension is } \\
\text { quite complete at a } \\
\text { normal rate of speech. }\end{array}$ & $\begin{array}{l}\text { Can discuss particular } \\
\text { interests of competence } \\
\text { with reasonable ease. } \\
\text { Rarely has to grope for } \\
\text { word. }\end{array}$ & $\begin{array}{l}\text { Errors never interfere } \\
\text { with understanding and } \\
\text { rarely disturb the native } \\
\text { speaker. Accent may be } \\
\text { obviously foreign. }\end{array}$ \\
\hline 4 & $\begin{array}{l}\text { Able to use the } \\
\text { language accurately } \\
\text { on all levels } \\
\text { normally pertinent } \\
\text { to professional } \\
\text { needs. Errors in } \\
\text { grammar are quite } \\
\text { rare. }\end{array}$ & $\begin{array}{l}\text { Can understand and } \\
\text { participate in any } \\
\text { conversations within the } \\
\text { range of his experience } \\
\text { with a high degree of } \\
\text { precision of vocabulary. }\end{array}$ & $\begin{array}{l}\text { Can understand any } \\
\text { conversation within } \\
\text { the range of his } \\
\text { experience. }\end{array}$ & $\begin{array}{l}\text { Able to use the } \\
\text { language fluently on } \\
\text { all levels normally } \\
\text { pertinent to } \\
\text { professional needs. } \\
\text { Can participate in any } \\
\text { conversation within } \\
\text { the range of this } \\
\text { experience with a high } \\
\text { degree of fluency. }\end{array}$ & $\begin{array}{l}\text { Error in pronunciation are } \\
\text { quite rare. }\end{array}$ \\
\hline 5 & $\begin{array}{l}\text { Equivalent to the of } \\
\text { an educated native } \\
\text { speaker. }\end{array}$ & $\begin{array}{l}\text { Speech non all levels is } \\
\text { fully accepted by educated } \\
\text { by educated native } \\
\text { speakers in all its features } \\
\text { including breadth of } \\
\text { vocabulary and idioms, } \\
\text { colloquialisms, and } \\
\text { pertinent } \\
\text { references. }\end{array}$ & $\begin{array}{l}\text { Equivalent to that of } \\
\text { an educated native } \\
\text { speaker. }\end{array}$ & $\begin{array}{l}\text { Has complete fluency } \\
\text { in the language such } \\
\text { that his speech is fully } \\
\text { accepted by educated } \\
\text { native speakers. }\end{array}$ & $\begin{array}{l}\text { Equivalent to and fully } \\
\text { accepted by educated } \\
\text { native speakers. }\end{array}$ \\
\hline
\end{tabular}

Brown (2001: 172-173)

Based on the assessment rubric above, researchers used a branch scale. If students get 5 meaning students are very good in aspects of speaking, if students get 4 means students are good in aspects of speaking, if students get 3 means that students are sufficient in aspects of speaking, if students get 2 means not both in aspects of speaking, and if students get 1 it means that it is not very good in aspects of speaking.

\section{Guessing Game Pic-Pow Strategy}

In education cannot be separated from learning and teaching activities. Learning and teaching are very close to the process of receiving knowledge from the introduction to the recipient. Learning is a conscious activity needed by someone. For the success of the teaching and learning process there must be a special way, one specific way is to use a strategy. The overall approach relating to the implementation of ideas, planning, and execution of an activity in a certain period of time.

Haidin \& Salim (2012:102) stated that learning strategy is a general approach and a series of actions that will be taken and used by the teacher to select several appropriate learning methods in learning, for example learning strategies that guide active participation of students will certainly not use lecture methods, group project work, tutorials, packages for learning packages independent.

From those statements above, it can be synthesized that a teacher must have a strategy in teaching their students to be more interesting and not bored while learning, after having a strategy then there must be a series of actions to find out which method is suitable to be applied to students in the teaching and learning process in the classroom, to be more active and make the classroom life. 
Guessing game is a game where an individual or a group tries to answer a question that has been given a number of keywords related to the word. It can be said as an interesting game for children, besides being simple, this game can help English teachers improve students' speaking.

According to Prawiyata, (2018:307), "Guessing Games is a game in which the participants compete individually or in teams to identify something that indicate obscurely". In addition, Webster (2001: 8) said that in teaching speaking through guessing games, students are expected to be involve datively in speaking class activity; they are much courage to think what they want to say. In other words, by guessing game students more active and interest in learning speaking.

Basen on statements above, it can be synthesized that Guessing Game is a game consisting of several people or groups, one of which gives a group that gives chunks to the picture that will be explained and the group others guess the picture. By using this guessing game application students will be more active and think hard to guess the picture.

\section{How to Play Application Guessing Game Pic-Pow Strategy}

Guessing game is a game that can help students more actively learn in the class, many ways to apply this guessing game. Then in the main activities the teacher begins this stage by introducing the first lesson by using guessing game strategy, here are some of the procedures in apply guessing game strategy in the class. Supriyatna (2014:08) stated that some rules in guessing game can choose and adjust depend on the material and situation in the class, as follows:

a. Four students are asked to come to the front of the classroom. One of them is selected to draw a slip from a box which contains words related to many different categories.

b. The students who has drawn a slip from a box which contains words related to many different categories.

c. The other members of the class try to guess the word on the slip which has been drawn from the box. They take turn asking about the category, "is it a word for food? For transportation?" the four students who have seen the slip take turns answering "No, it isn't until the right category has been guessed.

d. After the correct category has been discovered (transportation, for instance) members of the class continue to ask Yes/No questions: "is the word bus? Is it taxi? Is it train?"

e. The one whose guessing is correct may draw a slip from the box the next time the game is played.

According Prawiyata (2018:308), “Guessing that a common game can be applied in teaching, namely by using question sentences beginning with the word what or who and continuing by describing using verbs or nominal sentences, such as I am, It is ..., I have ... It can ... It eats ... It likes ... Depends on the object or object in question".

Based on statements about, the researcher can conclude some of the procedures in apply guessing game in the class, as follows:

a. First, the teacher give a task to students

b. Second, the teacher provides several pictures of tourist attractions for students, then students describe the picture in front of class.

c. Third, each student choose the image the teacher has provided. After that, the teacher asks students to make clues or keywords minimal 9 sentences from the picture they will explain in front of class.

d. Next, each student comes to class to describe the tourist attractions they have chosen, and the other students guessed the tourist attraction. That the students explained in front of the class, by looking at the image on the PowerPoint which is covered with pieces of color. The student who gives a presentation mentions the clue or keyword, the pieces of the image will be opened little by little.

e. Step d continues until the clues run out and the image is clear. 
Pic-pow is an example of learning media that uses ICT (Information communication and technology) with the Microsoft Power Point program. Power Point is one of the applications developed by Microsoft Power Point which is used for making presentations. Although this application program is actually a program for making presentations, existing facilities can be used to create a Language learning program.

According to Sianipar (2018:04), "With the PowerPoint Application, we can display, edit and produce impressive presentations wherever we are, with an intuitive touch experience designed for telephone or cable". Students can access presentations in the background, from all devices. Access files anywhere with the application.

From those statements above, it can be synthesized that PowerPoint is an Application that helps in presentation activities and also helps in accessing files anywhere. The facilities available at Microsoft power point Ouda (2003:4) says that can be used to make the display on the screen more attractive. Are as follows:

1. Enter text, image, sounds and videos,

2. Make an attractive appearance

3. Create a hyperlink that connects the display in a power point program with this application program.

With media pic-pow the teacher is expected to be able to teach something difficult to be easier and something complicated becomes simple. Choosing the right media such as the pic-pow media can help the teacher explain the lessons given. Besides that, the right media also helps students to form understanding in their souls.

\section{METHOD}

This research was conducted at Senior High School Mathla'ul Anwar Menes. It is located on Jl. Raya Labuan Km. 28 Kebon jeruk- Menes - Pandeglang. The reason why this school became place of the research because based on experience of the researcher when the researcher did the teaching practice in this school, the school had good quality teachers but most of students still had low of English skill especially in speaking.

In this research, the researchers used quantitative research design which a quasi-experimental design since the researcher wants to know the Influence of Application Guessing Game Pic-Pow Strategy on Students' Speaking Mastery. According to the subject of this study, in teaching speaking the researcher applied Pic-Pow strategy at the experimental class and SPE (Exposition Strategy) at control class.

The population of this research are the X MIA grade of Senior High School Mathla'ul Anwar Menes is one hundred ninety two students in total. In taking sample, the researcher choose class $X$ MIA 2 as controlled class which has twenty nine students, and class X MIA 1 as experimental class which has thirty students. So the researcher used fifty nine students for the sample.

Table 2. Population of the Research

\begin{tabular}{llll} 
Class & Male & Female & Total \\
\hline X MIA 1 & 14 & 16 & 30 \\
X MIA 2 & 13 & 16 & 29 \\
\hline Total & $\mathbf{2 7}$ & $\mathbf{3 2}$ & $\mathbf{5 9}$ \\
\hline
\end{tabular}

Sample is part of the population studied in a study and the results will be considered to be a picture of the original population, but not the population itself. Regarding to sugiyono (2014:81), "Sample is part of the number and characteristics of the population". In this research, the technique used in choosing the sample is systematic sampling. It means that the researcher taken part of tenth grade students' of Mathla'ul Anwar senior high school Menes which amount two classes as sample of the research. The classes consists of the experimental class and as control class. 
The experimental class teacher speaking by using application guessing game pic-pow strategy. Then, the class control teacher speaking by using SPE (Exposition Strategy).

Table 3. Sample of the Research

\begin{tabular}{llll}
\hline No & Class & Total Students & Sample Classes \\
\hline 1 & X MIA 1 & 30 & Experimental Class \\
2 & X MIA 2 & 29 & Control Class \\
\hline & Total & 59 &
\end{tabular}

The researcher used pre-test and post-test to collect the data. Pre-test and post-test would be given to the both of experimental class and controlled class. The procedure in this quasi-experimental design as follow:

1. Pre-test

In this research, before treatment the researcher gave oral test by asking question to both experimental and controlled class about their understanding related about the material that's about descriptive text especially about describing tourist attraction.

2. Treatment

Both of the class would treat differently. It can be explained as follows:

a. Experimental class

In this class, the application guessing game pic-pow strategy would apply as a treatment for teaching about speaking mastery.

b. Controlled class

In this class, the researcher would taught about speaking with SPE (Exposition Strategy).

3. Post-test

The post-test would conduct in the last meeting to measure students' speaking mastery after getting the treatment. The researcher would give an oral test again. Similar with the pre-test, the both student experimental class and controlled class describe their argument and understanding about descriptive text such as about describing tourist attraction.

\section{Validity}

In testing the validity of the instrument, the research did it through factor analysis by correlating the factors one another. The formula used in validity test is Person Product Moment formula as follow:

$$
\mathrm{r}_{\mathrm{i}}=\frac{\mathrm{n} \sum X_{i} Y_{i}-\left(\sum X_{i}\right)\left(\sum Y_{i}\right)}{\sqrt{\left[n \sum X_{i}^{2}-\left(\sum X_{i}\right)^{2}\right.} \mathbf{I} n \overline{\left.\sum Y_{i}^{2}-\left(\sum Y_{i}\right)^{2}\right]}}
$$

Where:

$$
\text { Sugiyono (2017:356) }
$$

$$
\begin{array}{ll}
\mathrm{ri} & =\text { Correlation coefficient } \\
\mathrm{n} & =\text { Number of respondent } \\
\sum X_{i} & =\text { Number of item scores } \\
\sum Y_{i} & =\text { Total score }
\end{array}
$$

\section{Reliability}

Instrument reliability testing could be done using the two split technique from superman Brown (Split Half). The following formulas and calculation examples are given in superman Brown:

$$
\mathrm{ri}_{\mathrm{i}} \quad=\frac{2 r_{b}}{1+r_{b}}
$$

Sugiyono (2017:359)

Where:

$$
\begin{array}{ll}
r_{\mathrm{i}} & =\text { internal reliability of all instruments } \\
r_{b} & =\text { Product moment correlation between the first and second }
\end{array}
$$


In this research, the researcher used oral test to gain some information and data about the topic of this research before the data were analyzed. This research highlights speaking mastery, the test used as instrument in this research are oral test, which were divided into pre-test and post-test. Moreover, for the materials, the researcher adapted with the school based Curriculum Development, English syllabus, textbook, and certain topics learned by the first grade students of Mathla'ul Anwar Menes.

\section{The Technique of Data Analysis}

Before analyzing the data using T-Test, the researcher also investigated the mean and standard deviation of the student speaking mastery by the formula as follows;

1. Mean

Mean is a group explanation technique based on the value of the group.

According to Abdurahman et al (2014:95), "Mean is the sum of all data values divided by the amount of data". To find the mean the researcher used the formula regarding Abdurahman et al (2014:96):

a) Mean of Experimental Group

$\mathrm{x}=\frac{\sum f_{i X_{i}}}{\sum f_{i}}$

Where:

$\mathrm{X}_{\mathrm{i}} \quad=$ the midpoint of each class

$\mathrm{f}_{\mathrm{i}} \quad$ = frequency of each class

2. Standard Deviation

Variance is the sum of squares of the difference in the observed value with a calculated average for the number of observations. While the standard deviation is the roof of the variety. For the population, the variance is calculated the formula the formula regarding Sugiyono (2017:57):

$$
\begin{aligned}
& \mathrm{S}=\sqrt{\frac{\sum f i(x i-x)^{2}}{n-1}} \\
& \text { Where: } \\
& \begin{array}{ll}
\mathrm{X}_{1} & =\text { Middle value to class }-\mathrm{i} \\
\mathrm{N} & =\text { Large population data } \\
\mathrm{n} & =\text { the Amount of sample data } \\
\mathrm{f}_{\mathrm{i}} & =\text { Class frequency }-\mathrm{i}
\end{array}
\end{aligned}
$$

3. Assumption Test

1). The Normality of Data Distribution

The normality of data distribution is done to measure the distribution of the data whether it is normal or not. The formula used in the test of normality of data distribution is Lififoers. The formula is researcher as follow:

$\mathrm{L}=\mid \mathrm{F}(\mathrm{Zi})-\mathrm{S}(\mathrm{Zi})$

If L-Count $\leq \mathrm{L}$-Table, the samples are normal

If L-Count > L-Table, the sample are not normal.

2). The Homogeneity of the Sample

The homogeneity of the sample is do to measure whether the sample of both classes homogeny or not. The formula used in testing the homogeneity of the sample is $\mathrm{F}$ test. The formula is researcher as follow:

$\mathrm{F}=\frac{\text { Big Variant }}{\text { Small Variant }}$

If F-Count $\leq \mathrm{F}$-Table, the samples are homogeny

If F-Count $>$ F-Table, the samples are not homogeny

In this research, the researcher used statistical computation, including scoring the result of the test, calculating the mean of both experimental and control group. Besides, she calculated the standard 
deviation of each group and then find out the significant differences by using t-test. The researcher uses the following formula:

a. Mean

b) Mean of Experimental Class

$$
\overline{\mathrm{Xe}}=\frac{\sum f_{i X_{i}}}{\sum f_{i}}
$$

c) Mean of Control Class

$$
\overline{\mathrm{x}_{\mathrm{c}}}=\frac{\sum f_{i Y_{i}}}{\sum f_{i}}
$$

Where:

$\overline{\mathrm{X}}_{\mathrm{e}} \quad=$ Mean of experimental class

$\overline{\mathrm{x}}_{\mathrm{c}} \quad=$ Mean of control class

$\mathrm{f}_{\mathrm{i}} \quad=$ Frequent of each class

$\mathrm{x}_{\mathrm{i}} \quad=$ The midpoint of experimental class

$\mathrm{y}_{\mathrm{i}} \quad=$ The midpoint of control class

b. T-test

$$
\mathrm{t}=\frac{X e-X c}{\sqrt{\frac{S D e^{2}}{N e}+\frac{S D c^{2}}{N c}}}
$$

Where:

$$
\begin{aligned}
& \mathrm{t} \quad=\mathrm{t} \text { value } \\
& \mathrm{Xe}=\text { Mean of experimental class } \\
& \mathrm{X}_{\mathrm{c}}=\text { Mean of control class } \\
& \mathrm{SDe}^{2}=\text { The square of the standard deviation of experimental class } \\
& \mathrm{SDc}^{2}=\text { The square of the standard deviation of control class } \\
& \mathrm{Ne}=\text { The total of the standard of the experimental class } \\
& \mathrm{Nc}=\text { The total number of the control class }
\end{aligned}
$$

\section{DISCUSSIONS}

In processing the data, firstly the researcher tried to collect the data about students' speaking mastery achievement through pre-test and post-test. After conducting the observation to the result of the test score, the researcher calculated and analyzed the data to know whether there is an influence of guessing game pic-pow strategy in students' speaking mastery.

1. Pre-Test

a. Normality of Experimental Class and Control Class

Normality test is carried out to determine whether the data obtained is normally distributed or not. Normality test of the two classes is done by testing Chi-Quadrate, using Microsoft Excel 2013 calculations, the results of calculations can be seen in the table below.

\begin{tabular}{lccc}
\multicolumn{4}{l}{ Table 4. Normality Calculation Pre-Test Experimental and Control Class } \\
\hline \multicolumn{1}{l}{ Class } & $\chi^{2}$ count & DF & $\chi^{2}$ table \\
\hline Control & 7,90 & 5 & 11,07 \\
\hline Experimental & 6,05 & 5 & 11,07 \\
\hline
\end{tabular}

Based on the calculations from experimental class and control class using Chi-Quadrate, in table 4.1 comparing $\chi^{2}$ count and $\chi^{2}$ tabel, for Df $=\mathrm{k}-1=6-1=5$, then obtained $\chi^{2}$ count 7,90 from control class and $\chi^{2}$ count 6,05 from experimental class with $\chi^{2}$ table 11,07 . 
Based on the previous statements, the researcher can conclude that the data of Pre-Test both two classes from experimental class and control class are normally distributed.

b. Homogeneity Test

After knowing the level of normality of the data then the homogeneity is then performed. Homogeneity test is used to determine the level of variance between two classes, experimental class and control class and the homogeneity test can be done by manual calculation.

Table 5. Homogeneity Test Pre-Test Experimental and Control Class

\begin{tabular}{lll}
\hline \multirow{2}{*}{ Value of Sample Variant } & \multicolumn{2}{l}{ Comparison of Pre-Test Values } \\
\cline { 2 - 3 } & $\begin{array}{l}\text { Experimental } \\
\text { class }\left(\mathrm{A}_{1}\right)\end{array}$ & Control class $\left(\mathrm{A}_{2}\right)$ \\
\hline $\mathrm{S}$ & 7,611 & 10,27 \\
\hline $\mathrm{S}^{2}$ & 57,927 & 105,472 \\
\hline $\mathrm{N}$ & 30 & 29 \\
\hline
\end{tabular}

Based on the calculation results obtained $\mathrm{F}_{\text {count }}=1,82$ with significance rates $\alpha=0,05$ comparing the value of $\mathrm{F}_{\text {count }}$ and $\mathrm{F}_{\text {table }}$ with $\mathrm{df}$ pembilang $=\mathrm{n}-1=30-1=29$ (for the big variant) and $\mathrm{df}$ penyebut $=n-1=29-1=28$ (for the small variant) then obtained $F_{\text {table }}=1,87$. Because $F_{\text {count }} \leq F_{\text {table }}$ or $1,82 \leq 1,87$ the researcher can conclude that both two classes have homogeneous variants.

2. Post-Test

a. Normality of Experimental Class and Control Class

Normality test is carried out to determine whether the data obtained is normally distributed or not. Normality test of the two classes is done by testing Chi-Quadrate, using Microsoft Excel 2013 calculations, the results of calculations can be seen in the table below.

Table 6. Normality Calculation Post-Test Experimental and Control Class

\begin{tabular}{llcc}
\hline Class & $\chi^{2}$ count & DF & $\chi^{2}$ table \\
\hline Control & 8,33 & 5 & 11,07 \\
\hline Experimental & 8,35 & 5 & 11,07 \\
\hline
\end{tabular}

Based on the calculations from experimental class and control class using Chi-Quadrate, in table 4.3 comparing $\chi^{2}$ count and $\chi^{2}$ table, for Df $=k-1=6-1=5$, then obtained $\chi^{2}$ count 8,33 from control class and $\chi^{2}$ count 8,35 from experimental class with $\chi^{2}$ table 11,07 .

Based on those statements above, the researcher can conclude that the data of Post-Test both two classes from experimental class and control class are normally distributed.

b. Homogeneity Test

After knowing the level of normality of the data then the homogeneity is then performed. Homogeneity test is used to determine the level of variance between two classes, experimental class and control class and the homogeneity test can be done by manual calculation. 
Table 7. Homogeneity Test Post-Test Experimental and Control Class

\begin{tabular}{|c|c|c|}
\hline \multirow{2}{*}{$\begin{array}{c}\text { Value of Sample } \\
\text { Variant }\end{array}$} & \multicolumn{2}{|c|}{ Comparison of Post-Test Values } \\
\hline & Experimental class $\left(\mathrm{A}_{1}\right)$ & Control class $\left(\mathrm{A}_{2}\right)$ \\
\hline$S$ & 17,23 & 16,50 \\
\hline $\mathrm{S}^{2}$ & 296,87 & 272,25 \\
\hline $\mathrm{N}$ & 30 & 29 \\
\hline
\end{tabular}

Based on the calculation results obtained $\mathrm{F}_{\text {count }}=1,09$ with significance rates $\alpha=0,05$ comparing the value of $\mathrm{F}_{\text {count }}$ and $\mathrm{F}_{\text {teble }}$ with $\mathrm{df}$ pembilang $=\mathrm{n}-1=30-1=29$ (for the big variant) and $\mathrm{df}$ penyebut $=n-1=29-1=28$ (for the small variant ) then obtained $F_{\text {table }}=1,87$. Because $F_{\text {count }} \leq F_{\text {table }}$ or $1,09 \leq 1,87$ the researcher can conclude that both two classes have homogeneous variants.

The analysis of the experimental class post-test and the control class post-test aimed to find out whether there is a significant difference in the post-test scores in the experimental class and the control class. Significance conclusion if tcount $\geq$ table at the level of significance $5 \%$ and $p \leq 0,05$. As for the summary of the post-test $t$-test of the experimental class and control class are addressed in the table below.

Table 8. T-test: Post-Test of Experimental and Control Class

\begin{tabular}{|c|c|c|c|c|c|}
\hline Class & & Mean & $t_{\text {count }}$ & $\mathrm{t}$ table & $\mathrm{P}$ \\
\hline \multicolumn{2}{|c|}{ Postest Control Class } & 79,29 & & & \\
\hline $\begin{array}{l}\text { Postest } \\
\text { Class }\end{array}$ & Experimental & 92,75 & 3,0858 & 1,672 & 0,000 \\
\hline
\end{tabular}

The results of pre-test t-test that known the mean of post-test experimental 92,75 and the mean of pre-test control class 79, 29. From the table is known tcount 3, 0858 with significance 0,000 . table from df 57 at the level of significance $5 \%$ is 1,672 . So tcount $\geq$ table $(3,0858 \geq 1,672)$ and the significance value is less than $0,05(\mathrm{p}=0,000 \leq 0,05)$. It can be concluded that the mean of learning outcomes of the experimental class are greater than the control class, therefore the speaking mastery of students who get application guessing game pic-pow strategy is better than students who get SPE (Exposition Strategy).

Based on those statements above, the researcher can conclude that $t_{\text {count }} \geq$ table or $3,0858 \geq 1$, 672 therefore $\mathrm{H}_{\mathrm{a}}$ is accepted and there is a significant influence of application guessing game pic-pow strategy towards students' speaking mastery.

Table 9. Recapitulation of Research Findings

\begin{tabular}{|c|c|c|c|c|}
\hline Analysis & Pre-Test & Post-Test & Decision & Conclusion \\
\hline $\begin{array}{l}\text { Normality Test of } \\
\text { Experimental Class }\end{array}$ & $\begin{array}{l}x^{2} \text { count }=6,05 \\
x^{2}{ }_{\text {table }}=11,07\end{array}$ & $\begin{array}{l}x^{2} \text { count }=8,35 \\
x^{2}{ }_{\text {table }}=11,07\end{array}$ & $x^{2}$ count $\leq x^{2}$ table & $\begin{array}{l}\text { Experimental class data are } \\
\text { normally distributed }\end{array}$ \\
\hline $\begin{array}{l}\text { Normality Test of } \\
\text { Control Class }\end{array}$ & $\begin{array}{l}x^{2} \text { count }=7,90 \\
x^{2}{ }_{\text {table }}=11,07\end{array}$ & $\begin{array}{l}x_{\text {count }}^{2}=8,33 \\
x_{\text {table }}^{2}=11,07\end{array}$ & $x^{2}$ count $\leq x^{2}$ table & $\begin{array}{l}\text { Control class data are } \\
\text { normally distributed }\end{array}$ \\
\hline $\begin{array}{l}\text { Homogeneity Test of } \\
\text { Experimental Class }\end{array}$ & $\begin{array}{l}F_{\text {count }}=1,82 \\
F_{\text {table }}=1,87\end{array}$ & $\begin{array}{l}F_{\text {count }}=1,09 \\
F_{\text {table }}=1,87\end{array}$ & $\mathrm{~F}_{\text {count }} \leq \mathrm{F}_{\text {table }}$ & $\begin{array}{l}\text { Experimental class data are } \\
\text { homogeny }\end{array}$ \\
\hline
\end{tabular}




\begin{tabular}{|c|c|c|c|c|}
\hline $\begin{array}{l}\text { Homogeneity Test of } \\
\text { Control Class }\end{array}$ & $\begin{array}{l}F_{\text {count }}=1,82 \\
F_{\text {table }}=1,87\end{array}$ & $\begin{array}{l}\mathrm{F}_{\text {count }}=1,09 \\
\mathrm{~F}_{\text {table }}=1,87\end{array}$ & $\mathrm{~F}_{\text {count }} \leq \mathrm{F}_{\text {table }}$ & $\begin{array}{l}\text { Control class data are } \\
\text { homogeny }\end{array}$ \\
\hline T-test & & $\begin{array}{l}T_{\text {count }}=3,0858 \\
t_{\text {table }}=1,672\end{array}$ & $\mathrm{~T}_{\text {count }} \geq$ ttable & 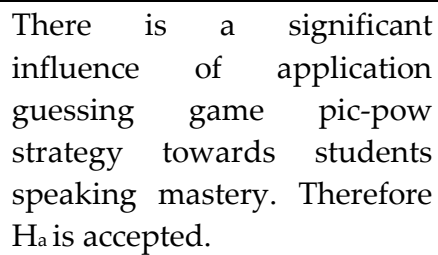 \\
\hline
\end{tabular}

Based on the calculation before on page 45, the researcher can conclude that there is a difference of speaking mastery between experimental class and control class. Therefore, there is an influence of the application guessing game pic-pow strategy towards students' speaking mastery with t-test results $T_{\text {count }} \geq$ table or $3,0858 \geq 1,672$. So it can be stated that students' speaking mastery who got application guessing game pic-pow strategy is better than SPE (Exposition Strategy), because there is a significant influence from the tcount of pre-test to post-test.

Based on the calculation results above, the students' speaking mastery who gets teaching with the application guessing game pic-pow strategy is better than the students' speaking mastery who gets teaching with SPE (Exposition Strategy). Guessing game is a game where an individual or a group tries to answer a question that has been given a number of keywords related to the word. It can be said as an interesting game for children, besides being simple, this game can help English teachers improve students' speaking.

In general, the experimental class students' who were the subjects in this research had a positive attitude towards English and their learning. It can be seen from the students' interest and sincerity towards English language learning so that during the course of learning it went smoothly, for students' responses to speaking mastery also showed a good tendency, as well as students' attitudes towards application guessing game pic-pow learning strategy were very interested and fun.

After learning in both classes are given treatment, there is speaking mastery seen from the value of the Pre-test and Post-test, showing that the students' speaking mastery who gets learning with application guessing game pic-pow strategy is better than students' speaking mastery who gets learning with SPE (Exposition Strategy). These Pre-test and Post-test score were then statistically tested to obtain more convincing result. From testing with $\mathrm{t}$-test obtained the value tcount $\geq$ table therefore the hypothesis $\mathrm{H}_{a}$ is accepted because there is a significance influence of application guessing game pic-pow strategy towards students' speaking mastery. Based on the relevant research above, the researcher can conclude that it is evident that the application guessing game pic-pow strategy provides a better effect on students' speaking mastery.

\section{CONCLUSION}

Speaking is productive skill in the oral mode, it is more complicated that seems a first and involved more than just pronouncing words. Regarding to this speaking skill need more vocabularies practice. Teaching speaking using guessing game pic-pow strategy gave students guidance to practice continuously in other to build their motivation and readiness to speak. Correction is an essential tool to guide students toward improvement. After conducting the research by giving pre-test and post-test to experimental class by using application guessing game pic-pow strategy and using SPE (exposition strategy) in control class, the researcher knows there is significant influence of suing application guessing game pic-pow strategy towards students' speaking mastery. Base on the result of t-test, the mean of experimental class is higher than the mean of control class. The result of post-test in experimental class has significantly improve ( $t$ value $\geq \mathrm{t}$-table $=3,0858 \geq 1,672$. It means that alternative hypothesis (Ha) is accepted. 


\section{REFERENCES}

Abdurahman, Maman et al. (2014). Dasar-Dasar Metode Statistika, Bandung: Penerbit CV. Pustaka Setia.

Brown, H. Douglas. (2004). Language Assessment Principles and Classroom Practice. American: Langman.

Haidin and Salim, (2012). Strategy Pembelajaran. Medan: Penerbit Perdana Publishing.

Iless Jaffe, Chella (2014). Public Speaking concepts and Skill for a diverse society. $8^{\text {th }}$ ed. Canada: Nelson Education, Ltd.

Nurrochman, S. (2013). The influence of Application Guessing Game strategy on Students' Speaking Ability of the First year Students of MTs Daru'l Hikam Cirebon

Prawinata, D.y. (2018). Penerapan guessing game untuk meningkatkan kosa kata Bahasa Inggris siswa SDN 101808 candirejo kecamatn biru. Prosiding Seminar Nasional Hasil Pengabdian 2018.

Sianipar, Pandapotan. (2018). Bekerja dengan PowerPoint 2016. Jakarta: Kelompok Gramedia, Anggota IKAPI.

Sugiyono. (2014). Metode Penelitian Kuantitatif, Kualitatif dan R \& D,Bandung: Penerbit Alfabeta.

Sugiyono. (2017). Statistika untuk penelitian, Bandung: Penerbit Alfabeta.

Supriyatna, Hari (2014). The effectiveness of Guessing Game technique in teaching Vocabulary at MTs Darussalam.

Wahyuni, S. (2015). The increasing Speaking Achievement by Using Pow-Tega Teachnique. International journal of English Language and Teaching https:// online-journal. unja.. ac.id/index. php/IJoLTE.

Wahyuni, and Yulianti, (2017). The use of guessing game to improving students' speaking skill.

Wardani, Basri, Waris, (2014). Improving the ability in writing descriptive text through guided-questions technique. e-Journal of English Language Teaching Society (ELTS).

Zaher, prof. Dr. aida Abd El Maksoud (2016). The effectiveness of a task-based instruction program in developing the English Language Speaking Skill of Secondary Stage Students. 